PENELITIAN

\title{
Pemeriksan Kultur Sekret sebagai Penunjang Diagnosis untuk Mengetahui Kejadian Ventilator Associated Pneumonia pada Pasien Pasca Pembedahan di Intensive Care Unit RSUP Dr. Kariadi Semarang
}

\section{Secrete Culture Examination as a Supportive Diagnostic for Ventilator Associated Pneumonia in Post-Surgical Patients at Intensive Care Unit Dr. Kariadi Hospital Semarang}

Anindito Andi Nugroho ${ }^{\otimes^{*}}$, Johan Arifin ${ }^{*}$, Hari Hendriarto ${ }^{*}$

*Bagian Anestesi dan Terapi Intensif, Fakultas Kedokteran, Universitas Diponegoro/ RSUP Dr. Kariadi, Semarang

${ }^{\triangle}$ Corespondence/ Korespondensi : aninditoandi@gmail.com

\section{ABSTRACT}

Background: Associated Ventilator Pneumonia (VAP) is defined as pneumonia that occurs 48 hours or more after endotracheal intubation and is characterized by progressive or recent infiltrates, systemic infection (fever, changes in leukocyte count), sputum changes, and the cause is found. VAP is the most common nosocomial infection in patients receiving mechanical ventilation. VAP incidence is half the cases of pneumonia acquired in the hospital.

Objective: Looking for VAP incidence in postoperative patients in ICU RSUP Dr. Kariadi Semarang with examination of secretion culture as supporting diagnosis, for 1216 weeks.

Methods: This study was designed as a descriptive observational study of all postoperative patients treated in ICU RSUP Dr. Kariadi Semarang, using mechanical ventilator for 48 hours or more, and meet inclusion criteria and take place within 12-16 weeks. Patients who performed the surgery were assessed for CPIS scoring, sent to the $I C U$, then aspirated their endotracheal secretions by using sterile mucous extractor to touch the endotracheal mucosal wall until all the mucous extractor tubes enter the ETT, then aspiration is sent to the microbiology laboratory. After the patient had ventilated the machine for 48 hours, the CPIS score was scored, then the patient was re-aspirated with endotracheal secretions using a sterile mucous extractor to touch the endotracheal mucosal wall (until all the mucous extractor tubes enter the ETT, aspiration results were sent to the microbiology laboratory. germ growth Determine VAP or not.

Result: There were 16 patients with 20-30 year olds, 1 patient (6.25\%), 31-40 years old, 2 patients (12.5\%), 41-50 years old, 5 patients (31.25\%), age 51-60 years as many as 8

Volume X, Nomor 2, Tahun 2018

Terakreditasi DIKTI dengan masa berlaku 3 Juli 2014 - 2 Juli 2019 
patients (50\%) with the growth of germs. This was confirmed by CPIS score> 6. 16 patients with male sex of 9 patients (56.25\%), and women as many as 7 patients (43.75\%).

Conclusions: The examination of the secret culture is an accurate diagnostic investigation of the diagnosis of VAP, and to identify the types of germs that develop, so that treatment can be done appropriately.

Keywords: CPIS; ETT; secretarial culture; VAP

\section{ABSTRAK}

Latar belakang: Ventilator Associated Pneumonia (VAP) didefinisikan sebagai pneumonia yang terjadi 48 jam atau lebih setelah intubasi endotrakeal dan ditandai dengan infiltrat progresif atau yang baru terjadi, infeksi sistemik (demam, perubahan jumlah leukosit), perubahan sputum, dan ditemukan penyebabnya. VAP merupakan infeksi nosokomial paling sering pada pasien yang mendapat ventilasi mekanik. Kejadian VAP merupakan separuh kasus pneumonia yang didapatkan di rumah sakit.

Tujuan: Menentukan kejadian VAP pada pasien pasca pembedahan di ICU RSUP Dr. Kariadi Semarang dengan pemeriksaan kultur sekret sebagai penunjang diagnosis, selama 12-16 minggu.

Metode: Penelitian ini dirancang sebagai penelitian observasional deskriptif terhadap semua pasien pasca pembedahan yang dirawat di ICU RSUP Dr. Kariadi Semarang, menggunakan ventilator mekanik selama 48 jam atau lebih, dan memenuhi kriteria inklusi dan berlangsung dalam waktu 12-16 minggu. Pasien yang dilakukan pembedahan dinilai skoring CPIS, dikirim ke ICU, kemudian diaspirasi sekret endotrakealnya dengan menggunakan mucous extractor steril hingga menyentuh dinding mukosa endotrakeal (hingga seluruh selang mucous extractor masuk ke dalam ETT, kemudian hasil aspirasi dikirim ke laboratorium mikrobiologi. Tunggu hasil pertumbuhan kuman. Setelah pasien tersebut terpasang mesin ventilator selama 48 jam, dinilai skoring CPIS, kemudian pasien kembali diaspirasi sekret endotrakealnya dengan menggunakan mucous extractor steril hingga menyentuh dinding mukosa endotrakeal (hingga seluruh selang mucous extractor masuk ke dalam ETT, hasil aspirasi dikirim ke laboratorium mikrobiologi. Tunggu hasil pertumbuhan kuman. Tentukan VAP atau bukan.

Hasil: Didapatkan 16 pasien dengan usia 20-30 tahun sebanyak 1 pasien (6,25\%), usia 31-40 tahun sebanyak 2 pasien (12,5\%), usia 41-50 tahun sebanyak 5 pasien (31,25\%), usia 51-60 tahun sebanyak 8 pasien (50\%) dengan pertumbuhan kuman. Hal tersebut dikuatkan dengan skor CPIS > 6. 16 pasien dengan jenis kelamin laki-laki sebanyak 9 pasien (56,25\%), dan perempuan sebanyak 7 pasien (43,75\%).

Simpulan: Pemeriksaan kultur sekret merupakan pemeriksaan penunjang diagnosis yang akurat pada penegakan diagnosis VAP, dan untuk mengetahui jenis kuman yang berkembang, sehingga dapat dilakukan pengobatan secara tepat.

Kata Kunci: CPIS; ETT; kultur sekret; VAP 


\section{PENDAHULUAN}

Ventilator Associated Pneumonia (VAP) didefinisikan sebagai pneumonia yang terjadi 48 jam atau lebih setelah intubasi endotrakeal dan ditandai dengan infiltrat progresif atau yang baru terjadi, infeksi sistemik (demam, perubahan jumlah leukosit), perubahan sputum, dan ditemukan penyebabnya. ${ }^{1}$ VAP merupakan infeksi nosokomial paling sering pada pasien yang mendapat ventilasi mekanik. ${ }^{1,2}$ Kejadian VAP merupakan separuh kasus pneumonia yang didapatkan di rumah sakit. ${ }^{1-3}$

Meskipun belum ada penelitian mengenai jumlah kejadian Ventilator Associated Pneumonia (VAP) di Indonesia, namun berdasarkan kepustakaan luar negeri yang lain diperoleh data bahwa kejadian VAP bervariasi antara 9-27\% angka kematiannya $27 \%$ bahkan sudah mencapai 43\%. ${ }^{4-6}$ Namun di ruang ICU RSUP Dr. Kariadi Semarang angka kejadian VAP justru sangat rendah bahkan mencapai $0 \%$ sehingga menyebabkan munculnya sebuah tanda tanya.

Mortalitas VAP meningkat tinggi bila infeksi disebabkan oleh patogen invasif multiresisten. $^{4-9}$ Keterlambatan diagnosis dan penatalaksanaan, berakibat buruk pada lama rawat di ICU, lama penggunaan ventilator, dan biaya rawat inap. $^{4-10}$

Penggunaan ventilator meningkatkan risiko infeksi nosokomial 6-21 kali dan tingkat kematian akibat VAP adalah 24$70 \%$ sehingga menyebabkan peningkatan rata-rata waktu yang dihabiskan di ICU menjadi 9,6 hari, dan juga menambah biaya pengobatan. Tambahan biaya yang harus dikeluarkan untuk pengobatan setiap pasien dengan VAP yaitu US \$ 40.000. ${ }^{11}$

Etiologi VAP meliputi spektrum mikroorganisme yang luas, dapat bersifat polimikrobial tetapi jarang disebabkan oleh jamur atau virus pada pasien imunokompeten. Perbedaan mikroorganisme antara satu tempat dengan yang lainnya dipengaruhi oleh populasi pasien di ICU, lama perawatan di rumah sakit dan ICU, metode diagnostik yang digunakan, pemberian antibiotika sebelumnya, dan lainlain. $^{5,6,10,11}$

Bakteri gram negatif aerob, infeksi kokus gram positif, infeksi polimikroba sering dilaporkan, prevalensinya bervariasi antara $13-60 \%$. Penyakit dasar yang dialami pasien VAP memungkinkan infeksi oleh kuman spesifik. Pasien dengan penyakit paru obstruktif kronik (PPOK) sangat mungkin terinfeksi Haemophylus influenzae, Streptococcus pneumoniae atau Moraxella catarrhalis, pasien fibrosis kistik paru berisiko terinfeksi Pseudomonas aeruginosa dan Staphylococcus aureus sedangkan pasien dengan trauma dan gangguan neurologi berisiko terinfeksi Staphylococcus aureus. $^{5,6,10,12}$

Kollef menyatakan insiden VAP tergantung pada lamanya paparan lingkungan, dan faktor risiko lain. Faktorfaktor risiko ini meningkatkan kemungkinan terjadinya VAP dengan cara meningkatkan terjadinya kolonisasi traktus aerodigestif oleh mikroorganisme patogen dan meningkatkan terjadinya aspirasi sekret yang terkontaminasi ke 
dalam saluran napas bawah. Cook dkk, menunjukkan bahwa lambung adalah reservoir utama kolonisasi dan aspirasi mikroorganisme. Hal ini dapat dipengaruhi beberapa faktor seperti pemakaian obat yang memicu kolonisasi bakteri (antibiotika dan pencegah stress ulcer), posisi pasien yang datar, pemberian nutrisi enteral, dan derajat keparahan penyakit pasien. ${ }^{12-14}$

Pencegahan VAP dapat dilakukan dengan 2 cara, yaitu secara non farmakologi dan memakai farmakologi. ${ }^{4,15}$ Pencegahan non farmakologi belum mampu menurunkan insiden VAP, maka kemudian ditambahkan dengan pencegahan secara farmakologi yang lebih efektif., ${ }^{6,12}$ Pemakaian antibiotika dapat meningkatkan risiko terjadinya resistensi kuman, sehingga penggunaan zat anti septik menjadi alternatif pilihan. ${ }^{16}$

Sekitar 63\% pasien VAP yang dirawat adalah pasien pasca pembedahan. Hal ini sesuai dengan penelitian Rello dkk, bahwa insiden dan angka mortalitas pasien VAP tinggi terutama pada pasien pasca trauma sebanyak $28-40 \%{ }^{17}$

Diagnosis yang cepat dan akurat diperlukan untuk meningkatkan tingkat kesembuhan pasien. Beberapa kriteria yang biasa digunakan untuk mendiagnosis VAP antara lain peninjauan manifestasi klinis, teknik pencitraan, interpretasi spesimen cairan broncho-alveolar

(Broncho-alveolar liquid atau BAL), respon biomarker penjamu. $^{18,19}$

Diagnosis VAP diambil setelah pasien diyakini tidak terkena pneumonia sebelumnya. Nilai CPIS lebih dari 6 dapat digunakan untuk mendiagnosis kejadian VAP pada pasien, sedangkan bila CPIS dibawah 6 diagnosa VAP dapat disingkirkan. ${ }^{14}$

Metode diagnostik yang akurat diperlukan untuk optimalisasi manajemen terapi infeksi. Gold standard yang digunakan selama ini yaitu kultur mikroorganisme di media tumbuh kembang. ${ }^{20}$

\section{METODE}

Penelitian dilaksanakan pada bulan Desember 2016-Maret 2017 kepada semua pasien pasca pembedahan yang dirawat di ICU RSUP Dr. Kariadi Semarang, menggunakan ventilator mekanik selama 48 jam atau lebih. Penelitian ini dirancang sebagai penelitian observasional deskriptif. Populasi penelitian adalah semua pasien usia 19-60 tahun pasca pembedahan yang dirawat menggunakan ventilator mekanik selama 48 jam atau lebih di ICU RSUP Dr. Kariadi Semarang.

Pasien yang dilakukan pembedahan dinilai skoring CPIS, dikirim ke ICU, kemudian diaspirasi sekret endotrakealnya dengan menggunakan mucous extractor steril hingga menyentuh dinding mukosa endotrakeal (hingga seluruh selang mucous extractor masuk ke dalam ETT, kemudian hasil aspirasi dikirim ke laboratorium mikrobiologi. Tunggu hasil pertumbuhan kuman.

Setelah pasien tersebut terpasang mesin ventilator selama 48 jam, dinilai skoring CPIS, kemudian pasien kembali diaspirasi sekret endotrakealnya dengan menggunakan mucous extractor steril hingga menyentuh dinding mukosa 
endotrakeal (hingga seluruh selang mucous extractor masuk ke dalam ETT, hasil aspirasi dikirim ke laboratorium mikrobiologi. Tunggu hasil pertumbuhan kuman. Tentukan VAP atau bukan.

\section{HASIL}

Enam belas pasien di ruang ICU RSUP Dr. Kariadi Semarang pasca dilakukan pembedahan, dilakukan perawatan pasca pembedahan di ICU dengan menggunakan ventilator mekanik selama 48 jam atau lebih, memenuhi kriteria inklusi dan pasien ataupun keluarganya bersedia menandatangani informed consent diikutsertakan dalam penelitian ini.

Selanjutnya dilakukan pemeriksaan kultur sekret pertama yaitu pada saat awal masuk ICU dan pemeriksaan kultur sekret kedua yaitu pada saat 48 jam penggunaan ventilator. Pengambilan sampel dengan menggunakan mucous extractor dengan cara endotracheal aspirate melalui ETT. Hasil endotracheal aspirate pada tabung mucous extractor kemudian dikirimkan ke laboratorium mikrobiologi RSUP Dr. Kariadi.

Tabel 1. Data usia pasien

\begin{tabular}{lll}
\hline \multicolumn{1}{c}{ Usia } & \multicolumn{1}{c}{ Frekuensi } & Persentase \\
\hline $19-20$ tahun & 0 & $0 \%$ \\
$21-30$ tahun & 1 & $6,25 \%$ \\
$31-40$ tahun & 2 & $12,5 \%$ \\
$41-50$ tahun & 5 & $31,25 \%$ \\
$51-60$ tahun & 8 & $50 \%$ \\
\hline Jumlah & 16 pasien & $100 \%$ \\
\hline
\end{tabular}

Dari data sampel pasien yang telah dilakukan pemeriksaan kultur sekret didapatkan 16 pasien dengan usia 20-30 tahun sebanyak 1 pasien $(6,25 \%)$, usia 31 -40 tahun sebanyak 2 pasien (12,5\%), usia 41-50 tahun sebanyak 5 pasien (31,25\%), usia 51-60 tahun sebanyak 8 pasien (50\%). Adapun jenis kelamin pasien dapat dilihat pada tabel 2 .

Tabel 2. Data jenis kelamin pasien

\begin{tabular}{lll}
\hline \multicolumn{1}{c}{ Jenis kelamin } & Frekuensi & Persentase \\
\hline Laki - laki & 9 & $56,25 \%$ \\
Perempuan & 7 & $43,75 \%$ \\
\hline Jumlah & 16 pasien & $100 \%$ \\
\hline
\end{tabular}


Dari data sampel tersebut didapatkan 16 pasien dengan jenis kelamin laki-laki sebanyak 9 pasien $(56,25 \%)$, dan perempuan sebanyak 7 pasien $(43,75 \%)$.

Pemeriksaan kultur sekret pertama dilakukan pada semua pasien tersebut dengan cara pengambilan endotracheal aspirate dalam tabung mucous extractor pada saat pasien awal pasien dirawat di ICU dengan menggunakan ventilator mekanik, yang kemudian sampel sekret tersebut dikirim ke laboratorium mikrobiologi RSUP Dr.
Kariadi untuk dilakukan pembiakan kuman, setelah sebelumnya dilakukan skoring CPIS terlebih dahulu.

Pemeriksaan kultur sekret kedua dilakukan pada semua pasien tersebut dengan cara yang sama dengan pengambilan kultur sekret pertama, dengan tetap menilai skoring CPIS pada pasien tersebut, kemudian menunggu hasil pembiakan kuman.

Pada penelitian ini dapat pula dibedakan status pembedahan pada pasien tersebut. Hal ini dapat dilihat pada tabel 3 .

Tabel 3. Status pembedahan pada pasien

\begin{tabular}{lll}
\hline \multicolumn{1}{c}{ Status pembedahan } & Frekuensi & Persentase \\
\hline Elektif & 12 & $75 \%$ \\
Cito & 4 & $25 \%$ \\
\hline Jumlah & 16 pasien & $100 \%$ \\
\hline
\end{tabular}

Dapat kita lihat berdasarkan tabel, status pembedahan dibedakan menjadi dua yakni elektif/ terprogram dan cito/ segera. Adapun hasilnya adalah pasien dengan status pembedahan elektif sebanyak 12 pasien (75\%), status pembedahan cito sebanyak 4 pasien $(25 \%)$.

Dari data penelitian ini dapat dibedakan pula dari jenis operasinya, terdapat dua jenis operasi yakni operasi bersih dan operasi kotor, dimana definisi operasi bersih adalah operasi dilakukan pada daerah/ kulit yang pada kondisi prabedah tanpa peradangan dan tidak membuka traktus respiratorius, traktus gastrointestinal, orofaring, traktus urinarius, dan traktus bilier. Operasi berencana dengan penutupan kulit primer dengan atau tanpa pemakaian drain tertutup. Sedangkan operasi kotor dapat didefinisikan sebagai operasi pada traktus digestif, traktus urogenitalis, atau traktus respiratorius yang terinfeksi. Melewati daerah purulen, luka terbuka lebih dari 6 jam setelah kejadian atau terdapat jaringan non vital yang luas atau yang nyata kotor. Pembagian jenis operasi tersebut dapat dilihat pada tabel 4 .

Tabel 4. Jenis Operasi

\begin{tabular}{cll}
\hline Jenis operasi & Frekuensi & Persentase \\
\hline Operasi bersih & 7 & $43,75 \%$ \\
Operasi kotor & 9 & $56,25 \%$ \\
\hline Jumlah & 16 pasien & $100 \%$ \\
\hline
\end{tabular}


Dilihat pada tabel 4, dapat kita ketahui pasien dengan operasi bersih sebanyak 7 pasien $(43,75 \%)$, pasien dengan operasi kotor sebanyak 9 pasien $(56,25 \%)$.

Pada saat dilakukan pemeriksaan kultur sekret pertama didapatkan beberapa pasien yang hasil kulturnya sudah menunjukkan perkembangan kuman, namun secara klinis pasien tersebut dinilai baik, dan skor CPIS $<6$. Data awal ini adalah sebagai data pembanding dari hasil kultur sekret kedua. Adapun hasil pemeriksaan kultur sekret pertama tersebut dapat dilihat pada tabel 5 .

Tabel 5. Hasil kultur sekret pertama

\begin{tabular}{lll}
\hline Pasien & Skor CPIS 1 & \multicolumn{1}{c}{ Kultur sekret } \\
\hline 1 & 4 & $\begin{array}{l}\text { Diplococcus gram }(+), \text { kuman bentuk batang gram } \\
(-), \text { pseudohifa }(+), \text { yeast cell }(+)\end{array}$ \\
2 & 3 & Tidak ditemukan pertumbuhan kuman \\
3 & 1 & Tidak ditemukan pertumbuhan kuman \\
4 & 4 & Pseudomonas aeruginosa \\
5 & 3 & Enterobacter aeruginosa \\
6 & 1 & Tidak ditemukan pertumbuhan kuman \\
7 & 4 & Candida sp \\
8 & 5 & Staphylococcus aureus \\
9 & 4 & Candida sp \\
10 & 2 & Tidak ditemukan pertumbuhan kuman \\
11 & 4 & Diplococcus gram $(+)$, kuman batang gram $(-)$ \\
12 & 5 & Kuman batang gram $(-)$ \\
13 & 5 & Enterobacter faecalis, Candida sp, Escherecia coli \\
14 & 4 & Pseudomonas aeruginosa \\
15 & 4 & Tidak ditemukan pertumbuhan kuman \\
16 & 3 & Diplococcus gram (+), kuman batang gram $(-)$, \\
& & Klebsiella pneumoniae \\
\hline
\end{tabular}

Beberapa pasien berdasarkan tabel 5 sudah terdapat gambaran pertumbuhan kuman pada saat dilakukan pemeriksaan kultur sekret pertama yakni sebanyak 11 pasien $(68,75 \%)$, dan yang tidak terdapat pertumbuhan kuman sebanyak 5 pasien $(31,25 \%)$.

Pasien sampel penelitian yang telah dilakukan pemeriksaan kultur sekret pertama kemudian dilakukan pemeriksaan kultur sekret kedua yakni pada saat pemakaian ventilator mekanik selama 48 jam. Berikut adalah hasil pertumbuhan kuman pada pengambilan kultur sekret kedua, dapat dilihat pada tabel 6 . 
Tabel 6. Hasil kultur sekret kedua

\begin{tabular}{ccl}
\hline Pasien & Skor CPIS 2 & \multicolumn{1}{c}{ Kultur sekret } \\
\hline 1 & 5 & Klebsiella pneumoniae \\
3 & 3 & Tidak ditemukan pertumbuhan kuman \\
4 & 2 & Tidak ditemukan pertumbuhan kuman \\
5 & 4 & Pseudomonas aeruginosa \\
6 & 3 & Tidak ditemukan pertumbuhan kuman \\
7 & 2 & Tidak ditemukan pertumbuhan kuman \\
8 & 3 & Candida sp \\
9 & 3 & Staphylococcus aureus \\
10 & 4 & Candida sp \\
11 & 3 & Tidak ditemukan pertumbuhan kuman \\
12 & 3 & Diplococcus gram (+), kuman batang gram $(-)$ \\
13 & 4 & Klebsiella pneumoniae \\
14 & 4 & Klebsiella pneumoniae \\
15 & 3 & Diplococcus gram (+), kuman batang gram $(-)$ \\
16 & 4 & Candida sp \\
\hline
\end{tabular}

Dapat dilihat pada tabel 6, sebanyak 11 pasien $(68,75 \%)$ dengan pertumbuhan kuman pada pemeriksaan kultur sekret kedua dan sebanyak 5 pasien $(31,25 \%)$ tidak terdapat pertumbuhan kuman.
Bila dibandingkan antara hasil pemeriksaan kultur sekret pertama dan kedua dapat kita lihat hasilnya pada tabel 7.

Tabel 7. Perbandingan hasil pemeriksaan kultur sekret pertama dan kedua

\begin{tabular}{|c|c|c|c|}
\hline Pasien & Kultur 1 & Kultur 2 & $+/-$ \\
\hline 1 & $\begin{array}{l}\text { Diplococcus gram }(+) \text {, Kuman } \\
\text { bentuk batang gram }(-) \text {, }\end{array}$ & Klebsiella Pneumoniae & + \\
\hline 2 & $\begin{array}{l}\text { Tidak ditemukan pertumbuhan } \\
\text { kuman }\end{array}$ & $\begin{array}{l}\text { Tidak ditemukan pertumbuhan } \\
\text { kuman }\end{array}$ & - \\
\hline 3 & $\begin{array}{l}\text { Tidak ditemukan pertumbuhan } \\
\text { kuman }\end{array}$ & $\begin{array}{l}\text { Tidak ditemukan pertumbuhan } \\
\text { kuman }\end{array}$ & - \\
\hline 4 & Pseudomonas aeruginosa & Pseudomonas aeruginosa & - \\
\hline 5 & Enterobacter aeruginosa & $\begin{array}{l}\text { Tidak ditemukan pertumbuhan } \\
\text { kuman }\end{array}$ & - \\
\hline
\end{tabular}


6 Tidak ditemukan pertumbuhan kuman

$7 \quad$ Candida sp

8 Staphylococcus aureus

9 Candida $\mathrm{sp}$

10 Tidak ditemukan pertumbuhan kuman

11 Diplococcus gram (+), kuman batang gram (-)

12 Kuman bentuk batang gram (-),

13 Enterobacter faecialis, Candida $\mathrm{sp}$, Escherechia coli

14 Pseudomonas aeruginosa

15 Tidak ditemukan pertumbuhan kuman

16 Diplococcus gram (+), kuman bentuk batang, Klebsiella
Tidak ditemukan pertumbuhan kuman

Candida sp

Staphylococcus aureus

Candida sp

Tidak ditemukan pertumbuhan kuman

Diplococcus gram $(+)$, kuman batang gram (-)

Klebsiella pneumoniae

Klebsiella pneumoniae

Diplococcus gram $(+)$, kuman batang gram (-)

Candida $\mathrm{sp}$

Klebsiella pneumoniae
Dari tabel 7, dapat kita lihat perbandingan hasil kultur sekret pertama dan kedua, terdapat sebanyak 1 pasien dengan hasil kultur sekret pertama tidak ada pertumbuhan kuman dan pada hasil kultur sekret kedua didapatkan hasil pertumbuhan kuman, sebanyak 1 pasien pula dengan hasil kultur sekret pertama didapatkan pertumbuhan kuman dan kultur sekret kedua tidak terdapat pertumbuhan kuman. Terdapat juga sebanyak 4 pasien tidak terdapat pertumbuhan kuman pada pemeriksaan kultur sekret pertama dan kedua, dan sebanyak 10 pasien terdapat pertumbuhan kuman pada pemeriksaan kultur sekret pertama dan kedua.

Dari hasil tersebut dapat kita gunakan sebagai pembanding untuk menganalisa kejadian VAP atau bukan, dalam hal ini kejadian tersebut dapat dikatakan VAP atau hanya dikatakan sebagai Hospital-associated pneumonia (HAP). Dapat digunakan pula sebagai pembanding jenis kuman pada pemeriksaan kultur sekret pertama dan kedua.

Menurut hasil tersebut diatas peneliti menyimpulkan terdapat sebanyak 4 pasien (25\%) dapat didiagnosis sebagai VAP, dan beberapa lainnya dapat disingkirkan adanya kejadian VAP. Hasil tersebut mendekati angka kejadian VAP di dunia berdasarkan kepustakaan yang ada.

\section{PEMBAHASAN}

Ventilator Associated Pneumonia (VAP) didefinisikan sebagai pneumonia yang terjadi 48 jam atau lebih setelah 
intubasi endotrakeal dan ditandai dengan infiltrat progresif atau yang baru terjadi, infeksi sistemik (demam, perubahan jumlah leukosit), perubahan sputum, dan ditemukan penyebabnya. ${ }^{1}$ VAP merupakan infeksi nosokomial paling sering pada pasien yang mendapat ventilasi mekanik. ${ }^{1,2}$ Kejadian VAP merupakan separuh kasus pneumonia yang didapatkan di rumah sakit. ${ }^{1-3}$

Berdasarkan American Thoracic Society, pneumonia nosokomial (lebih dikenal sebagai Hospital-acquired pneumonia atau Healthcare-associated pneumonia) didefinisikan sebagai pneumonia yang muncul 48 jam atau lebih, di rawat di rumah sakit tanpa pemberian intubasi endotrakeal. Terjadinya pneumonia nosokomial akibat tidak seimbangnya pertahanan tubuh dan kemampuan kolonisasi bakteri sehingga menginvasi traktus respiratorius bagian bawah. Bakteri yang berperan dalam pneumonia nosokomial adalah Pseudomonas aeruginosa, Klebsiella spp, Staphylococcus aureus, Streptococcus pneumonia.

Sedangkan American College of Chest Physicians (2006) mendefinisikan VAP sebagai pneumonia yang terjadi 48 - 72 jam setelah pemasangan ventilator yang ditandai dengan suatu gambaran infiltrat baru atau infiltrat yang progresif dan menetap pada foto torak, tanda-tanda infeksi sistemik (demam dan tingginya white blood cell count) disertai salah satu tanda yaitu, hasil biakan darah atau pleura sama dengan mikroorganisme yang ditemukan di sputum maupun aspirasi trakea, kavitasi pada foto torak, gejala pneumonia atau terdapat dua dari tiga gejala berikut yaitu demam, leukositosis dan sekret purulen. 5,6,10,21,22

Pada banyak kasus, diagnosis pneumonia nosokomial dapat diketahui secara klinis, serta dibantu dengan kultur bakteri, termasuk kultur semikuantitatif dari sampel broncho-alveolar lavage $(\mathrm{BAL}){ }^{2,19}$

Sekitar 63\% pasien VAP yang dirawat adalah pasien pasca pembedahan. Hal ini sesuai dengan penelitian Rello dkk, bahwa insiden dan angka mortalitas pasien VAP tinggi terutama pada pasien pasca trauma sebanyak 28$40 \%{ }^{17}$

Diagnosis yang cepat dan akurat diperlukan untuk meningkatkan tingkat kesembuhan pasien. Beberapa kriteria yang biasa digunakan untuk mendiagnosis VAP antara lain peninjauan manifestasi klinis, teknik pencitraan, interpretasi spesimen cairan broncho-alveolar (Broncho-alveolar liquid atau BAL), respon biomarker penjamu. ${ }^{18,19}$

Meskipun belum ada penelitian mengenai jumlah kejadian Ventilator Associated Pneumonia (VAP) di Indonesia, namun berdasarkan kepustakaan luar negeri yang lain diperoleh data bahwa kejadian VAP bervariasi antara 9-27\% angka kematiannya $27 \%$ bahkan sudah mencapai 43\%. ${ }^{4-6}$ Namun di ruang ICU RSUP Dr. Kariadi Semarang angka kejadian VAP justru sangat rendah bahkan mencapai $0 \%$.

Berdasarkan data tersebut diatas, peneliti melakukan penelitian guna mengetahui angka kejadian VAP di RSUP Dr. Kariadi. Peneliti melakukan 
penelitian angka kejadian VAP di ICU RSUP Dr. Kariadi dengan menggunakan pemeriksaan kultur sekret sebagai penunjang diagnosis, pemeriksaan dilakukan pada saat pasien awal dirawat di ICU dengan menggunakan ventilator mekanik dan pemeriksaan kedua dilakukan 48 jam penggunaan ventilator mekanik di ICU RSUP Dr. Kariadi pada pasien pasca pembedahan baik status operasi elektif atau cito dan jenis operasi bersih maupun operasi kotor.

Sampel penelitian didapatkan dari pasien di RSUP Dr. Kariadi yang akan melakukan pembedahan dan kemudian dilakukan perawatan pasca pembedahan di ruangan ICU RSUP Dr. Kariadi dengan membutuhkan penggunaan ventilator mekanik selama 48 jam atau lebih. Pasien yang akan digunakan sebagai sampel tersebut telah dilakukan persetujuan dengan menandatangani inform consent baik oleh pasien maupun keluarga. Dalam sampel penelitian ini juga dilakukan skoring CPIS terlebih dahulu dan memenuhi kriteria inklusi sebagai sampel penelitian.

Penelitian ini menggunakan hasil biakan kuman pada kultur sekret pertama yakni pada saat pasien tersebut awal dirawat di ICU pasca pembedahan, dan kultur sekret kedua yakni pada saat pasien tersebut menggunakan ventilator mekanik 48 jam atau lebih dengan cara pengambilan kultur sekret menggunakan mucous extractor dengan cara endotracheal aspirate, kemudian hasil kultur sekret dikirim ke laboratorium mikrobiologi RSUP Dr. Kariadi.

Pada penelitian ini, peneliti melakukan pemeriksaan kultur sekret pada 16 pasien dengan hasil sebagai berikut. Dari data pasien yang telah dilakukan pemeriksaan kultur sekret didapatkan 16 pasien dengan usia 21 30 tahun sebanyak 1 pasien $(6,25 \%)$, usia 31 - 40 tahun sebanyak 2 pasien $(12,5 \%)$, usia $41-50$ tahun sebanyak 5 pasien $(31,25 \%)$, usia 51 - 60 tahun sebanyak 8 pasien (50\%). 16 pasien dengan jenis kelamin laki - laki sebanyak 9 pasien $(56,25 \%)$, dan perempuan sebanyak 7 pasien $(43,75 \%)$.

Dapat kita lihat berdasarkan tabel, status pembedahan dibedakan menjadi dua yakni elektif/ terprogram dan cito/ segera. Adapun hasilnya adalah pasien dengan status pembedahan elektif sebanyak 12 pasien (75\%), status pembedahan cito sebanyak 4 pasien (25\%). Dapat kita lihat pula jenis operasi didapatkan hasil pasien dengan operasi bersih sebanyak 7 pasien $(43,75 \%)$, pasien dengan operasi kotor sebanyak 9 pasien $(56,25 \%)$.

Beberapa pasien berdasarkan tabel 5 sudah terdapat gambaran pertumbuhan kuman pada awal dilakukan pemeriksaan kultur sekret yakni sebanyak 11 pasien $(68,75 \%)$, dan yang tidak terdapat pertumbuhan kuman sebanyak 5 pasien (31,25\%). Pada tabel 11, sebanyak 11 pasien $(68,75 \%)$ dengan pertumbuhan kuman pada pemeriksaan kultur sekret kedua dan sebanyak 5 pasien $(31,25 \%)$ tidak terdapat pertumbuhan kuman.

Dari tabel 7, dapat kita lihat perbandingan hasil kultur sekret pertama dan kedua, terdapat beberapa pasien dengan hasil kultur sekret pertama tidak ada pertumbuhan kuman dan pada hasil kultur sekret kedua didapatkan hasil 
pertumbuhan kuman, beberapa pasien pula dengan hasil kultur sekret pertama didapatkan pertumbuhan kuman dan kultur sekret kedua tidak terdapat pertumbuhan kuman. Terdapat juga beberapa pasien tidak terdapat pertumbuhan kuman pada pemeriksaan kultur sekret pertama dan kedua, beberapa juga yang terdapat pertumbuhan kuman pada pemeriksaan kultur sekret pertama dan kedua.

Dari hasil tersebut dapat peneliti gunakan sebagai pembanding untuk menganalisa kejadian VAP atau bukan, dalam hal ini kejadian tersebut dapat dikatakan VAP atau hanya di katakan sebagai Hospital-associated pneumonia (HAP). Dapat digunakan pula sebagai pembanding jenis kuman pada pemeriksaan kultur sekret pertama dan kedua.

Menurut hasil tersebut diatas peneliti menyimpulkan terdapat sebanyak 4 pasien $(25 \%)$ dapat didiagnosis sebagai VAP, dan beberapa lainnya dapat disingkirkan adanya kejadian VAP.

Pembahasan berdasarkan hasil tersebut peneliti melihat kejadian VAP lebih sering dan berisiko terjadi pada pasien-pasien dengan status operasi cito dan jenis operasi kotor. Operasi kotor dapat didefinisikan sebagai operasi pada traktus digestif, traktus urogenitalis, atau traktus respiratorius yang terinfeksi. Melewati daerah purulen, luka terbuka lebih dari 6 jam setelah kejadian atau terdapat jaringan non vital yang luas atau yang nyata kotor. Dalam hal status operasi cito peneliti menyimpulkan kejadian ini akibat dari kondisi pasien yang tidak optimal untuk dilakukan pembedahan dikarenakan pembedahan harus dilakukan secara segera dan tidak ada waktu yang cukup untuk mengkondisikan pasien secara optimal untuk dilakukan pembedahan. Untuk jenis operasi yang kotor lebih berisiko terjadi pertumbuhan kuman, peneliti melihat hal tersebut cukup wajar mengingat daerah yang dilakukan pembedahan adalah daerah-daerah yang sangat rentan ditumbuhi kuman walaupun tidak dilakukan pembedahan, sehingga kemungkinan pasti jauh lebih tinggi resiko untuk terjadinya pertumbuhan kuman pada pemeriksaan sekret.

Hasil dari pertumbuhan kuman dari data sampel penelitian bervariasi jenis kumannya. Didapatkan beberapa pasien dengan pertumbuhan kuman yang biasa menyebabkan kejadian VAP diantaranya adalah Klebsiella pneumoniae, Pseudomonas aeruginosa, Staphylococcus aureus, terdapat juga jamur, Candida $s p$, yang terdapat pada pertumbuhan kultur kuman.

Didapatkan pula hasil pertumbuhan kuman pada pemeriksaan kultur sekret pertama terdapat pertumbuhan kuman, dan pada pemeriksaan kultur sekret kedua tidak didapatkan pertumbuhan kuman, peneliti melihat hal tersebut dikarenakan jenis kuman yang tumbuh pada pemeriksaan kultur sekret pertama dapat diatasi dengan pemberian antibiotik yang adekuat dan penerapan VAP bundle sebagai SOP penatalaksanaan pasien di ICU sudah baik dan benar, sehingga kuman tersebut dapat diatasi.

Peneliti menyimpulkan berdasarkan tabel-tabel pertumbuhan kuman tersebut kejadian VAP bila pada hasil pemeriksaan kultur sekret pertama tidak didapatkan pertumbuhan kuman dan pada 
pemeriksaan kultur sekret kedua didapatkan hasil pertumbuhan kuman tertentu, atau pertumbuhan kuman antara hasil pertumbuhan kuman pada pemeriksaan kultur sekret pertama berbeda jenis kumannya dengan hasil pertumbuhan kuman pada pemeriksaan kultur sekret kedua dengan gejala-gejala yang menunjang kearah diagnosis pneumonia. Dari hasil yang peneliti amati terdapat 4 pasien $(25 \%)$ yang dapat peneliti diagnosis sebagai kejadian VAP.

Meskipun hal tersebut masih dapat dibantah dikarenakan pertumbuhan kuman selama 48 jam dapat pula terjadi karena kejadian HAP, yang kumannya baru tumbuh setelah 48 jam. VAP sendiri dibagi menjadi early onset (awitan dini) yang terjadi dalam 96 jam pertama setelah pemasangan ventilasi mekanis dan late onset (awitan lambat) yang terjadi lebih dari 96 jam setelah pemasangan ventilasi mekanis. ${ }^{28}$ Dari penjelasan definisi early onset VAP, kuman masih dapat tumbuh sampai 96 jam (4 hari), sedangkan pemeriksaan kultur sekret kedua peneliti lakukan pada 48 jam penggunaan ventilator.

Bagaimanapun hasil penelitian ini dilakukan ternyata penegakan diagnosis VAP dengan pemeriksaan kultur sekret sebagai penunjang diagnosis tetap lebih akurat untuk mendapatkan hasil diagnosis VAP secara tepat, sehingga dapat dilakukan pengobatan yang tepat. Pada beberapa kejadian yang peneliti amati, ada pasien yang diobati dengan antibiotik yang adekuat, dan setelah dilakukan pemeriksaan kultur sekret ternyata hasil pertumbuhan kumannya adalah candida $s p$, sehingga terapi yang diberikan menjadi tidak tepat. Jadi kesimpulan yang dapat peneliti ambil adalah pemeriksaan kultur sekret seharusnya dilakukan pada semua pasien yang ada di ICU dengan penggunaan ventilator mekanik.

Meskipun didapatkan hasil dari tabel-tabel tersebut, menurut peneliti masih terdapat beberapa bias yang terjadi, misalnya pada saat pengambilan kultur sekret endotrakeal kurang terjamin kesterilannya pada saat pengiriman sampel, dapat juga dari cara pengambilan sampel, misalnya pada saat pengambilan sampel sekret yang terambil adalah sekret dari dinding ETT. Namun demikian peneliti tetap meyakini dari hasil penelitian yang peneliti lakukan bahwa kejadian VAP di RSUP Dr. Kariadi Semarang adalah ada kejadian VAP walaupun hanya sedikit.

Rendahnya kejadian VAP di ICU RSUP Dr. Kariadi Semarang merupakan salah satu bukti tindakan penerapan VAP bundle yang cukup baik dan sesuai SOP penanganan pasien-pasien di ICU RSUP Dr. Kariadi Semarang.

\section{SIMPULAN}

Pemeriksaan kultur sekret merupakan pemeriksaan penunjang diagnosis yang akurat pada penegakan diagnosis VAP, dan untuk mengetahui jenis kuman yang berkembang, sehingga dapat dilakukan pengobatan secara tepat.

\section{DAFTAR PUSTAKA}

1. Kalanuria AA, Zai W, Mirski M. Ventilator-associated pneumonia in the ICU. Crit Care. 2014;18(2):208.

2. Porzecanski I, Bowton DL. Diagnosis and treatment of 
ventilator-associated pneumonia. Chest. 2006 Aug;130(2):597-604.

3. Sallam SA, Arafa MA, Razek AA, Naga M, Hamid MA. Devicerelated nosocomial infection in intensive care units of Alexandria University Students Hospital. East Mediterr Health J Rev Sante Mediterr Orient Al-Majallah AlSihhiyah Li-Sharq Al-Mutawassit. 2005 Mar;11(1-2):52-61.

4. Ibrahim EH, Tracy L, Hill C, Fraser VJ, Kollef MH. The occurrence of ventilator-associated pneumonia in a community hospital: risk factors and clinical outcomes. Chest. 2001 Aug;120 (2):555-61.

5. Ewig S, Bauer T, Torres A. The pulmonary physician in critical care - 4: Nosocomial pneumonia. Thorax. 2002 Apr 1;57(4):366-71.

6. Kollef MH. Prevention of hospitalassociated pneumonia and ventilator-associated pneumonia. Crit Care Med. 2004 Jun;32 (6):1396-405.

7. Rello J, Lorente C, Diaz E, Bodi $\mathrm{M}$, Boque C, Sandiumenge A, et al. Incidence, etiology, and outcome of nosocomial pneumonia in ICU patients requiring percutaneous tracheotomy for mechanical ventilation. Chest. 2003 Dec;124 (6):2239-43.

8. Afessa B, Shorr AF, Anzueto AR, Craven DE, Schinner R, Kollef MH. ASsociation between a silvercoated endotracheal tube and reduced mortality in patients with ventilator-associated pneumonia. Chest. 2010 May 1;137(5):101521.
9. Höffken G, Niederman MS. Nosocomial pneumonia*: The importance of a de-escalating strategy for antibiotic treatment of pneumonia in the icu. Chest. 2002 Dec 1;122(6):2183-96.

10. Ibrahim EH, Ward S, Sherman G, Kollef MH. A comparative analysis of patients with early-onset vs lateonset nosocomial pneumonia in the icu setting*. Chest. 2000 May 1;117(5):1434-42.

11. Ban KO. The effectiveness of an evidence-based nursing care program to reduce ventilatorassociated pneumonia in a Korean ICU. Intensive Crit Care Nurs. 2011 Aug 1;27(4):226-32.

12. Chastre J, Fagon J-Y. Ventilatorassociated Pneumonia. Am J Respir Crit Care Med. 2002 Apr 1;165 (7):867-903.

13. Toward understanding evidence uptake: Semirecumbency for pne...: Critical Care Medicine [Internet]. LWW. [cited 2017 Mar 18]. Available from: http:// journals.lww.com/ccmjournal/ Fulltext/2002/07000/

Toward_understanding_evidence_u ptake_.12.aspx

14. Chan EY, Ruest A, Meade MO, Cook DJ. Oral decontamination for prevention of pneumonia in mechanically ventilated adults: systematic review and metaanalysis. BMJ. 2007 Apr 26;334 (7599):889.

15. Pesola GR. Ventilator-associated pneumonia in institutionalized elders: Are teeth a reservoir for respiratory pathogens? Chest. 2004 Nov 1;126(5):1401-3. 
16. Dodek P. Evidence-Based Clinical

Practice Guideline for the Prevention of VentilatorAssociated Pneumonia. Ann Intern Med. 2004 Aug 17;141(4):305.

17. Tantipong $\mathrm{H}$, Morkchareonpong $\mathrm{C}$, Jaiyindee S, Thamlikitkul V. Randomized Controlled Trial and Meta-analysis of Oral Decontamination with $2 \%$ Chlorhexidine Solution for the Prevention of VentilatorAssociated Pneumonia. Infect Control Amp Hosp Epidemiol. 2008 Feb;29(2):131-6.

18. Rea-Neto A, Youssef NCM, Tuche F, Brunkhorst F, Ranieri VM, Reinhart K, et al. Diagnosis of ventilator-associated pneumonia: a systematic review of the literature. Crit Care. 2008;12:R56.

19. Kalil AC, Metersky ML, Klompas M, Muscedere J, Sweeney DA, Palmer LB, et al. Management of Adults With Hospital-acquired and Ventilator-associated Pneumonia: 2016 Clinical Practice Guidelines by the Infectious Diseases Society of America and the American Thoracic Society. Clin Infect Dis Off Publ Infect Dis Soc Am. 2016 Sep 1;63(5):e61-111.

20. Fournier P-E, Dubourg G, Raoult D. Clinical detection and characterization of bacterial pathogens in the genomics era. Genome Med [Internet]. 2014 Nov 29 [cited 2017 May 1];6. Available from: http://www.ncbi.nlm.nih.gov/ pmc/articles/PMC4295418/

21. Marik PE, Varon J. Ventilatorassociated pneumonia: Science and hocus-pocus. Chest. 2001 Sep 1;120(3):702-4.

22. American Thoracic Society, Infectious Diseases Society of America. Guidelines for the management of adults with hospital -acquired, ventilator-associated, and healthcare-associated pneumonia. Am J Respir Crit Care Med. 2005 Feb 15;171(4):388416. 